\title{
Improving Speaking Skills Using the Cooperative Method Jigsaw Technique for Third Grade Students of SD Negeri 3 Kedungbanteng
}

\section{Banyumas}

\section{Nia Ulfa Martha ${ }^{a 1^{*}}$, Dyah Wijayawati a2 \\ *author correspondence

\begin{tabular}{|c|c|}
\hline \multicolumn{2}{|c|}{ Article information } \\
\hline \multicolumn{2}{|c|}{ Article history: } \\
\hline Accepted: & I7 Januari 202I \\
\hline Revised & 30 September 2021 \\
\hline Published & 30 Oktober $202 \mathrm{I}$ \\
\hline
\end{tabular}

Pendidikan Bahasa Indonesia Program, Fakultas Ilmu Budaya, Universitas Jenderal Soedirman ${ }^{\mathrm{a}, \mathrm{b}}$ nia.martha@unsoed.ac.id ${ }^{1 *}$; dyah.wijayawati@,unsoed.ac.id ${ }^{2}$

Kata kunci:

Pembelajaran Berbicara

Metode Kooperatif Jigsaw

\begin{abstract}
ABSTRAK
Penelitian ini memiliki tujuan yang dapat dirumuskan antara lain (I) mendeskripsikan peningkatan keterampilan berbicara melalui metode kooperatif teknik jigsaw pada peserta didik kelas III SD Negeri 3 Kedungbanteng Banyumas; dan (2) mendeskripsikan perubahan perilaku peserta didik kelas III SD Negeri 3 Kedungbanteng Banyumas setelah diberikan pembelajaran keterampilan berbicara melalui metode kooperatif teknik jigsaw. Metode yang digunakan yaitu PTK. Dalam metode PTK peneliti membantu pengajar mengatasi masalah belajar keterampilan berbicara di kelas. Hasil pembelajaran berbicara siklus I 45\%, siklus II 55\%, dan siklus III $70 \%$. Kualitas pembelajaran berbicara, siklus I 46\%, siklus II $76 \%$, dan siklus III $87 \%$. Sesuai dengan hasil yang ditunjukkan, maka terdapat kenaikan tingat belajar keterampilan berbicara dengan metode kooperatif teknik jigsaw.

\section{ABSTRACT}

This research has a goal that can be formulated, among others (I) describes improving speaking skills through cooperative methods of jigsaw techniques in students of grade III State Elementary School 3 Kedungbanteng Banyumas; and (2) describe changes in the behavior of students of class III Elementary School 3 Kedungbanteng Banyumas after being given learning speaking skills through cooperative methods jigsaw techniques. The method used is PTK. In the PTK method researchers help teachers overcome problems learning speaking skills in the classroom. Learning outcomes speak cycle I 45\%, cycle II 55\%, and cycle III $70 \%$. The quality of speaking learning, cycle I $46 \%$, cycle II $76 \%$, and cycle III $87 \%$. In accordance with the results shown, there is an increase in learning speaking skills with cooperative methods of jigsaw techniques.
\end{abstract}

\section{Key word:}

Speaking Learning

Jigsaw Cooperative Methods

Copyright (C) 2018 Universitas Ahmad Dahlan. All Right Reserved

\section{Introduction}

Communication can be said to be good if it is supported by the ability to learn language. Learning languages, especially Indonesian, can improve students' skills when communicating using Indonesian either directly through words or in writing. The four aspects of language skills are listening, speaking, reading, and writing. These aspects are integrated when applied in the teaching and learning process. However, in the syllabus these aspects can be separated. (Azmi, 2019).

Moreover, (Azmi, 2019) explained that speaking skills are dynamic skills, if compared to the other aspects of language, in terms of using language. The ability to speak cannot be obtained by itself. Speaking abilities can be obtained by practicing continuously. In other words, language skills can be obtained by actively carrying out language activities. Students can practice in actual situations and conditions. By practicing like this, students will gain real experience. Good teaching for students in order to practice speaking skills is to give them as much freedom as possible to produce utterances in front of the public with the subject matter they master. Speaking activities such as speeches and others are necessary to be practiced.

Not much different from Azmi, Musaba (Musaba, 2012) stated that to be skilled at speaking, the right effort to be made by everyone is to practice speaking. Exercises that can be done by a person to practice speaking skills include: (I) attending or being directly involved in discussion activities, seminars, meetings, and others, (2) observing when other people are talking, (3) doing speaking exercises with others. observed by friends or family, and (4) participating in speech competitions if there is a chance. 
In the 2013 curriculum, Bahasa Indonesia learning at the elementary level has the aim of making students skilled in communicating (Ummah, 2020). Of the four aspects of skills, the skills that must be mastered and trained to students are speaking skills (Sukma, 2020). In this case, students are trained to convey various notifications related to speaking skills such as revealing information. The ability of students to express information can be seen through how students convey ideas and thoughts verbally (Zahara, 2020).

Meanwhile, (Rosita, 2015) explained that since students are in elementary school, learning to speak is taught so that students are able to express thoughts and ideas through the use of language which can be accepted by others. Next, (Permana, 2015) explained that the speaking skills of elementary school students could be trained by giving them time to express their opinions orally. The purpose of teaching speaking in elementary school is to provide training for them to be proficient and agile in speaking. There are several things i.e., fluency in speaking, coherence in speaking, and dexterity that need attention for teachers to teach speaking skills to their students.

Interviews conducted by the researchers with Bahasa Indonesia teachers for class III SD Negeri 3 Kedungbanteng Banyumas produced information of speaking learning methods. So far, teachers had used conventional methods: asking students one by one to introduce themselves in front of their classmates. The teacher only asked the students to come forward in front of the class to speak. Based on this, the researchers contemplated what method was appropriate to use to overcome the problem of learning speaking skills. The researcher had a solution, a method, which was then presented to the teacher to overcome the problem of learning speaking skills. The method is a cooperative method, jigsaw technique which is expected to be able to improve the teaching and learning process of speaking in class III SD Negeri 3 Kedungbanteng Banyumas. The design of the jigsaw cooperative learning model serves to foster a sense of responsibility of students towards information obtained by themselves and information obtained from others. The cooperative method, the jigsaw technique, is a method that invites students not only to familiarize themselves with the material for themselves, but also to try to provide material to their group. One of the experts who developed the jigsaw technique of cooperative learning is Elliot Aronson. (Yuliani, 2019). Further, (Febiyanti, Wibawa, \& Arini, 2020) explained that discussion or question and answer activities are cooperative method jigsaw technique. Discussion or question and answer activities were able to create a relationship between one learning object and another learning object, or between learning objects and the teacher, so that students' speaking skills are increasingly trained. Not much different from Yuliani and Febiyanti et al, Pujingsih (Pujingsih, 202I) revealed that the cooperative method jigsaw technique is a form of cooperative learning which supports learning objects that are always active in mastering the subject matter in order to achieve the best possible learning outcomes.

According to the previously stated background, efforts to improve speaking skills can be done through the use of the cooperative method jigsaw technique. Based on the previously mentioned rationales, the problems in this study deserve to be investigated. SD Negeri 3 Kedungbanteng Banyumas was located on Jalan Raya Kedungbanteng, Kedungbanteng Village, Kedungbanteng District, Banyumas Regency, Central Java Province. The location of SD Negeri 3 Kedungbanteng Banyumas was not far from the researchers' domicile. The location which was not far makes it easy for researchers to retrieve data. In addition, researchers focused on helping to overcome problems that occur in the environment around the researchers' domicile. Based on the results of observations at SD Negeri 3 Kedungbanteng Banyumas there were problems in learning speaking skills. These problems included students having difficulty when asked to speak in front of the teacher and their peers. Learning speaking skills refers to the knowledge and does not refer to language or speaking skills. Thus, the objectives of the study can be formulated as follows: (I) to describe the improvement of speaking skills through the cooperative method jigsaw techniques in third grade students of SD Negeri 3 Kedungbanteng Banyumas; and (2) to describe changes in the behavior of third grade students of SD Negeri 3 Kedungbanteng Banyumas after being taught speaking skills through the cooperative method jigsaw technique.

The collection of reference materials that serve as guidelines for carrying out this research are previous studies related to this research. Researches that discuss the teaching-learning process of speaking skills include Nupus and Parmiti, (2017), Mabruri and Aristya (2017), Muna, Degeng, and Hanurawan (2019), and Beta (2019). The description of several previous studies is Nupus and Parmiti (Nupus \& Parmiti, 2017), which proved the Show and Tell method was able to improve the speaking skills of grade III C students of SD Negeri 3 Banjar Jawa in the 2017/2018 school year. The learning stages carried out were: introducing the Show and Tell design; examples from teachers on how to apply show and tell; handing over to students within a certain time to do show and tell; the teacher asked the students to have a discussion. The teacher encouraged students to ask their questions and the teacher was open to answering questions from each student. Nupus' research has relevance to this research in the sense of researching speaking skills. The difference is, Nupus applied the Show and Tell method, while this study applied the cooperative method jigsaw technique. 
In addition, Mabruri dan Aristya (Mabruri \& Aristya, 2017) had finished their research. Based on the analysis of research data, the research they did was able to improve students' speaking skills with role playing strategies. In cycles I and II there was an increase in speaking skills. The average score of the students was 7I and achieved a completion of $50.90 \%$. This average score was achieved by IO students. The average value of the first cycle was $76.4 \mathrm{I}$ with $75.68 \%$ or I3 students had passed. The students' average score of 82 and $90.64 \%$ passed. This average score was achieved by 18 students. Mabruri's research has relevance to this research, in a sense of researching speaking skills. The difference is, Mabruri used a role playing strategy, while this study used the cooperative method jigsaw technique.

Moreover, Muna, Degeng, dan Hanurawan (Muna, 2019) had also conducted a research. Based on the analysis of research data, an increase occurred in the results of the research they had done. This research was able to improve students' speaking skills through image media. The application of picture media in the teaching and learning process of speaking in the fourth grade of elementary school proved that there was an increase in students' speaking skills. Students were able to communicate well when learning to speak using image media. This showed that the problem of learning speaking could be solved after doing Classroom Action Research (CAR/PTK). With picture media, the teaching-learning process of speaking improved. Of the 28 students, $82 \%$ (22 students) were able to get a minimum passing grade of $75 \%$. Muna et al's research had relevance to this study, which is researching speaking skills. The difference is, Muna et al used image media, while this study used the cooperative method jigsaw technique.

Another researcher, Beta (Beta, 2019) had also conducted a research. Based on the analysis of research data, improvement occurred in the learning of students' speaking skills through the role-playing method. The roleplaying method used by fifth grade students at SD Negeri 65 Pajalesang Palopo had improved their speaking skills. The average result of the students' speaking skill acquisition reached 80.58, which was in the good category. While classically, $82.35 \%$ passed and was also in the good category. The previous description explains that the research conducted by Beta showed an increase. Beta's research has relevance to this research, which is researching speaking skills. The difference is, Beta used a role-playing method, while this study used the cooperative method jigsaw technique.

\section{Methods}

Classroom Action Research (CAR/PTK) was exploited for this research. According to Simanjuntak, Manullang, dan Sinaga (Simanjuntak, 2017) CAR is a research method used by teachers to improve or overcome learning problems that occur in their classrooms. Researchers carried out research activities at SD Negeri 3 Kedungbanteng Banyumas. The choice of place is based on the school which had problems in learning speaking skills. The research was conducted by observing the third grade of the mentioned elementary school as the subject of research. The collaborators in this study were the third grade teacher. The researchers used two information gathering techniques. First, the method of collecting information regarding the series of teaching and learning processes of speaking skills which included, observation, document analysis, and interviews. Second, how to collect information about the income of learning speaking skills. The method used to measure students' mastery of speaking skills was by giving a test. There are two measuring instruments used; those are the written test and the oral test. The method of solving the information used was critical analysis.

\section{Results and discussions}

The four stages in this research included: (I) planning, (2) action, (3) observation, and (4) reflection, which were carried out in three cycles.

1. Cycle I

a. Planning

The researchers and the teacher carried out: (I) communicating the design of speaking skills learning through the cooperative method jigsaw technique, (2) the teacher made the lesson plans for speaking skills through the cooperative method jigsaw technique, (3) the researchers together with collaborators make preparations in the form of children's fairy tale books as learning materials, and (4) the researchers and the teacher design research tools, such as performance assessment and observations results assessment. The appearance of students in storytelling was measured by an assessment tool in the form of performance. Meanwhile, the results of researchers' observations during learning are measured by an assessment tool in the form of observation.

The first cycle of the first meeting in the planning section included: (a) the teacher gave 
encouragement to students to take a big part in the teaching and learning process, (b) the teacher observed the experiences that students had in storytelling, (c) the teacher provided information about learning steps then students were divided into five groups according to the part of the story that would be shared. The teacher formed eight original groups consisted of students with different abilities; each group consists of five students, (d) the teacher divided the eight original groups into five expert groups, (e) then the teacher asked the students to join the expert group and discussed the part the story obtained, ( $f$ ) the teacher discussed the story that would be conveyed by the students during the lesson, and $(\mathrm{g})$ the lesson was closed by the teacher.

Activities at the planning stage of the first cycle of the second meeting were: (a) the teacher conveyed the material that had been taught at the previous meeting, (b) after a brainstorming activity in front of the expert group according to the previous meeting, students could go to their respective groups to convey the results of discussions with the expert group, (c) presentation activities were carried out after students exchanged ideas with both the expert group and the original group. Presentations were useful for unifying the views of the learning that had been done, (d) all students individually took objective tests related to stories, (e) teachers and students hold reflections, and (f) in the last activity the teacher ended the learning process of storytelling skills.

b. Action

Activities at this stage were: (a) the teacher greeted the students, then the teacher asked the students questions relating to the material to be delivered by connecting old knowledge with new knowledge about fairy tale speaking skills, (b) the teacher provided information in the form of a brief explanation about the storytelling material as the students paid attention to the explanation from the teacher, (c) the teacher divided the students into five groups based on the part of the story that was shared. Then the teacher formed eight original groups. The teacher, in the next activity, asked students to go back to their own groups so that it would be easy for the teacher to give grades. The division of groups was adjusted according to the order of the students' numbers in attendance list, (d) then the teacher divided the eight original groups into five expert groups which had the task of studying the part of the story that had been obtained and then discussing it, (e) the teacher gave each group a part of the story of fairy tales; the stories between groups were different, and each student got two pieces of story parts, ( $f$ ) the teacher had a discussion together with students about fairy tales, and $(\mathrm{g})$ the teacher ended the teaching and learning process.

The activities of the cycle I of meeting II included the following activities: (a) the teacher checked the attendance of students and tried to remind students about the material that had been taught previously, (b) students joined a group that was considered to be proficient in mastering the material to re-understand the part of the story that had been given; after that the students told what they had obtained from the expert group to teach it back to the group members so that it became a complete story, (c) the presentation was conducted after finishing asking questions with the expert group or their group. The presentation was done by drawing several groups. Each group showed various information obtained to unify the views of the material, (d) all students individually worked on the objective test and the results were then collected, (e) based on group stories, the teacher provided guidance to students to conclude or assess the learning activities that have been passed, and ( $f$ ) the teacher concluded the learning activity by encouraging students to always be happy and giving greetings in closing.

c. Observation

The researcher observed teacher when carrying out teaching and learning activities in the classroom by retelling the content of fairy tales in the third grade of SD Negeri 3 Kedungbanteng Banyumas classroom. The researcher's position was in the back of the classroom so as not to interfere with the teaching and learning process. On this occasion, the teacher taught fairy tale material with the fairy tale title "Lembu dan Burung Hantu". The series of learning carried out by the teacher used the cooperative method jigsaw technique. Using this method, the teacher no longer read the available fairy tales, but students were asked to learn them first. The teacher only read the description briefly. Bahasa Indonesia learning could be described as follows: (a) researchers and teachers discussed together to make learning plans as guidelines for carrying out learning, (b) In speaking skills learning, teachers had implemented conceptual learning patterns. That was, the teacher in carrying out learning had a clear basis. The teacher encouraged the enthusiasm of students to participate in the success of the teaching and learning process at the beginning of learning. Next, the teacher tried to question the students about the material they had learned, namely the skill of fairy tale storytelling. As well as providing an explanation of the method used, (c) the teacher formed eight original groups, each group consisted of five students and the teacher advised students to immediately unite with the original group. 
Furthermore, the content of the fairy tale was divided into five parts which were then distributed to each expert group. Each group got a different part of the story. Next, students were asked to discuss the content of the fairy tales that would be taught to the original group. After finishing the discussion, one class was divided into five expert groups, each group consisting of eight students. The teacher took one student from the original group to serve as an informant. Then, students were asked to discuss and exchange information about the content of fairy tales that students had obtained when they gathered with the expert groups in a coherent manner. The results of the discussion were written on a piece of paper, (d) from the obtained discussion results, each group was asked to present a fairy tale story in a coherent way from the beginning of the story to the end with their own language and sentences according to their understanding, (e) each group was asked to tell a story about a fairy tale that they had learned, other groups' activities when their friends told stories were listening while noting important things, (f) after each group had done storytelling activities, students were asked for their opinions about the fairy tales that had been told, (g) the teacher made an assessment on the learning that had been done based on the opinions expressed by the students, $(h)$ then, the teacher ended the storytelling learning by motivating the students to always be healthy and happy.

Observations of learning speaking skills could be seen in the enthusiasm and activation of students: (a) students who were enthusiastic when the teacher provided learning experiences about learning that have passed and look for relationships with the material to be taught in speaking skills were $20 \%$, while $80 \%$ of students did not seem to pay attention when learning took place, (b) students who were enthusiastic were $60 \%$. Meanwhile, $40 \%$ of the students were less enthusiastic about being involved in learning activities. This situation showed the attitude of students who point at each other to come to the front of the class, and invested more their time in joking with their peers, and (c) students who were able tell stories are 55\%, while there were $45 \%$ students who weren't able to do storytelling activities. Seeing from the condition of the students at the time of telling stories, they still looked unprepared, some even trembled and were afraid, which affected their abilities to tell stories. A conclusion could be drawn from these activities that the students' intention in learning speaking activities in cycle I was $45 \%$.

The behavior of the students which could be observed were: (a) the students' pronunciation in speaking was in the medium category. Three of the students were classified able to speak with good pronunciation, (b) from the use of grammar, 25 students were classified moderate and I6 students were lacking, (c) from fluency, when telling stories 5 students were fluent, 20 students were moderate, and 16 students were not fluent, and (d) from the students' understanding of the stories shared, 20 students were able to tell stories correctly and 2I other students were still not correct. From overall behavior, there were $46 \%$ students who could get a score of 6.5 .

Some of the shortcomings of the teacher were: (a) the teacher seemed to spend a lot of time doing lectures in front of his students, this resulted in the teacher not being able to monitor the students who at that time were at the back seat. Not only that, the students who were in the front corner were still joking around and (b) the teacher was not able to take advantage of the opportunity to manage learning as well as possible, all this was because the time given to exchange opinions exceeds the planned time so that time for practice story was a little less. The shortcomings which could be seen from the perspective of students included: (a) teachers needed a lot of time to repeat the lessons delivered because students were not enthusiastic in participating in learning activities, (b) during the question and answer activity, not all students participated; students actually enjoyed playing with their friends more. Conditions like this that led to the students' less coherent performance when telling stories because students lacked a sense of responsibility, (c) students did not realize the advantages they had so that they felt less confident; in other words they were still reluctant or embarrassed if asked to speak, and still pointing at each other so they wasted a lot of time, and (d) most students seemed unable to do speaking activities. Students were nervous so they forgot what to say.

d. Reflection

The reflections obtained from learning speaking were: (a) the teacher did not stand in front of the class but walked around moving towards the students' seats during the lesson. Not only that, the teacher did not reprimand students who did not pay attention to the activities of the teaching and learning process, (b) the sense of responsibility for the group had not been seen in students so that they tended not to care about the tasks given by the teacher so that students did not have the ability to exchange ideas properly, (c) motivating students to want to participate in the learning activities carried out, (d) students had not been able to convey their ideas in front of their friends, because students had a feeling of fear if they spoke they will be laughed at by their friends, and teachers tried to support students so that they were happy to provide feedback and tell stories about fairy tale.

2. Cycle II 
In this cycle, the activities carried out were students telling fairy tales together with their group members in front of other groups. Students were allowed to determine their own group. After that, the group representative chose a part of the story. The teacher had given the task to choose a group, and the story part was obtained at the meeting that day.

a. Planning

The planning activities carried out in this cycle were: (I) through discussion between the researcher and the teacher, the design of the teaching-learning process for speaking skills was obtained, including: (a) the teacher tried to encourage the students to be active in the teaching-learning process of storytelling, then conveyed how important speaking skills were, (b) the teacher assigned students to form eight original groups of five student members, (c) the teacher formed eight original groups that had been created by students into five expert groups, (d) students joined the expert group and discussed the part of the story that was obtained, (e) the teacher had discussions with students about the part of the fairy tale that was learned, (f) the teacher closed the learning activity, and (g) students were asked to discuss about the part of the story that had been given in the expert group so that they understood it. (2) for future activities, researchers and teachers designed lesson plans, and (3) together with teachers, researchers made instruments in the form of behavioral assessments and observations. The performance of students in front of the class when telling stories was assessed by the teacher with the performance assessment. Then, during the storytelling lesson, the researcher evaluated the results of the observations.

At the planning stage of the second cycle, the first meeting consisted of the following activities: (a) students were given a list of student names to decide their groups with the directions from the teacher, (b) students were given the opportunity to prepare the previous material, which was distributed by the teacher, and asked them to study at home, (c) the teacher gave encouragement to students who felt they did not have the courage to tell stories. In addition, the teacher encouraged students to have a sense of responsibility towards the group, and (d) the teacher occasionally walked to the middle and the back of the classroom to explain the material as well as in conditioning students..

The planning stage of the second cycle of the second meeting was: (a) the teacher explained or repeated the material that had been previously explained and connected it with the material to be taught to submit a learning experience aimed at the students, (b) after finishing discussing in the expert group, the students returned to their original group to inform about what had been discussed in the expert group, (c) the teacher gave grades to the group that appeared in front of the class without being forced, (d) students individually took quizzes, and (e) the teacher provided feedback after learning activities finished.

The actions of the second cycle of the first meeting were: (a) the teacher started the learning activity by greeting the students and conditioning the classroom atmosphere, (b) the teacher encouraged the students to be active and to pay attention to the teaching and learning process. Next, the teacher explained briefly about the storytelling skill materials, (c) the teacher asked the names of the groups and the names of their members who had been formed by students in the previous activity to serve as an expert group, (d) students were expected to be able to interact with the expert group and discussed the part of the story that had been obtained to be accounted for in the original group, (e) the teacher asked about the material that had been given before, and $(\mathrm{f})$ the teacher ended the storytelling learning activity.

Activities in the form of actions that could be carried out in the second cycle of the second meeting were: (a) at the beginning, the teacher took attendance and asked how the students were doing, (b) the teacher connected the lessons that had been taught with the lessons to be taught, (c) the students held discussions with the original group in order to get a coherent and clear part of the story, (d) the teacher gave appreciation to the group who was able to show their ability to tell stories smoothly in front of their friends, (e) students began to provide answers to questions posed by the teacher on a piece of paper, (f) the teacher and students held a reflection session to get the same the perception regarding the story, and $(\mathrm{g})$ the teacher ended the lesson by giving words of encouragement so that students didn't forget to be happy and jolly.

b. Observation

The researcher observed the teacher who was carrying out the teaching-learning process by sitting at the back of the class. Learning began with an introduction; the teacher greeted the students and asked how they were and also checked the presence of students because the lesson started just after the break was over. In addition, teachers also conditioned the students so that they were not noisy and ready to get the lessons. Like the previous implementation, the teacher taught speaking skills as taught in cycle I which aimed to refresh the students' memories. The teacher then explained the steps of the storytelling learning activity that 
would be carried out and asked the names of the groups that had been previously formed at the last meeting to become the expert groups. After that, the teacher asked the students to join the expert group and then the students were asked to discuss the material they had studied before, before they returned to their original group. After they returned to their original group, they also had a discussion to put together the parts of the story that they had learned. Then one of the representatives from several groups was asked to come forward to tell a fairy tale story in front of the class. After a group representative came forward, students took multiple choice tests or objective tests to measure students' understanding of the content of the fairy tales.

After the lesson ended, at the next meeting the teacher invited the students to recall the contents and messages of the fairy tales they had learned before, then the teacher asks students to join the original group to complete part of the story. Then representatives from several groups presented the story in front of the class. In this case, the students seemed more courageous to speak in front of the teacher and their classmates in the same class compared to the previous cycle. The teacher also praised the students who weren't afraid to appear and tell stories coherently in front of the class. Furthermore, from the responses given by the teacher, then the teacher and students made conclusions and reflected on the teaching and learning process that had been carried out.

Based on the researchers' observations, the teacher was getting used to the method used, while the students were getting interested in learning speaking skills. Observations of the teaching-learning speaking which could be conveyed were: (a) students who were enthusiastic in apperception during teaching and learning activities were $30 \%$, while the other $70 \%$ did not pay attention to the teacher's explanations, (b) students who were active during teaching and learning activities were $70 \%$ while the other $30 \%$ were still less active in participating in lessons, and (c) students who were able to tell stories seriously were $65 \%$, while the other $35 \%$ are still unable to tell stories correctly and coherently.

Thus, it could be concluded that the tendency of students to listen to storytelling learning activities in cycle II was $55 \%$. As for the results of student performance, it could be seen as follows: (a) assessed from the pronunciation, 3I students spoke with moderate pronunciation, and only IO students were able to speak with good pronunciation, (b) there were 3 students who received an assessment of the use of grammar language correctly, 33 students who used grammar at a moderate level and 5 students were still not able to use correct grammar when telling stories in front of the class, (c) assessed by fluency when telling stories, there were 26 students who told stories fluently, and I5 students told stories with moderate fluency, and (d) assessed from students' understanding of the characters in the story, 25 students were able to tell the identity of the idol figures correctly and 16 other students were still not correct. From the overall performance results, only $76 \%$ of students were able to exceed the passing grade, which was getting a score of 6.5. Weaknesses were still clearly visible from students. Those weaknesses were that students were still less active and less responsible when holding discussions.

c. Analysis and reflection

Storytelling learning activities using the cooperative method jigsaw techniques in the third grade SD Negeri 3 Kedungbanteng Banyumas could be carried out smoothly. The weaknesses that appeared in the second cycle began to be addressed. Students had started to give responses, although they werre still less active in groups. In the second cycle, there was an improvement and in this cycle there was already readiness from the previous cycle.

3. Cycle III

a. Planning

At the planning stage of the cycle III, things carried out by researchers and the teacher as a collaborator were: (I) researchers collaborated with the teacher to design speaking skills learning scenarios, (2) the teacher and researchers prepared Lesson Plans (RPP) for speaking skills material, and (3) researchers and teachers designed research assessment measuring tools in the form of performance and observation assessments. The appearance of students telling stories in front of the teacher and their friends was assessed by performance assessment. Storytelling learning activities in class were assessed by observational assessment.

The planning of the third cycle of the first meeting was: (a) the teacher asked the students the previous material to be connected with the speaking skills material in order to provide a learning experience to the students, (b) the teacher tried to provide information on the stages of the teaching-learning process, (c) the teacher divided the eight original groups and the students were expected to be in groups, (d) the teacher made the eight original groups into five expert groups, (e) students were asked to discuss the fairy 
tales that had been given to the expert group so that they understood it, ( $f$ ) after discussing with the group proficient, students returned to the original group to inform the results of the discussion with the advanced group, and $(\mathrm{g})$ the teacher ended the storytelling lesson by giving encouragement and reminded them to be happy.

The planning of cycle III meeting II was: (a) the teacher reminded the students of the previous material, (b) when the discussion with the expert group was finished, the students went to their group to inform the results of the discussion with the expert group, (c) the teacher suggested the students to be brave to tell stories in front of the teacher and their friends in groups to tell fairy tales in front of their friends, (d) the teacher distributed a test to measure the ability of students' understanding of the content of the tale; the test was carried out objectively, (e) the teacher gave gifts to students who were able to tell the contents of fairy tales coherently and clearly, and ( $f$ ) the teacher provided feedback to find out how far the students had mastered the lessons that had been taught.

b. Action

The actions of the third cycle of the first meeting were: a) the teacher started the storytelling lesson by saying greetings then checking the attendance list by calling the names of students one by one; (b) the teacher tried to connect the knowledge that had been learned with the lesson to be explained; (c) the teacher explained the stages of the activities carried out, (d) the teacher encouraged students to join the expert group; group members were selected based on the score of the students' ability to tell stories, (e) students were asked to discuss the part of each story with the expert group; (f) once the students finished discussing in the expert group, students go to the original group to inform the results of the discussion from the expert group, (g) the teacher had discussions with the students and then the teacher closed the learning activity, and $(h)$ the teacher ended the storytelling teaching-learning process.

The actions of cycle III meeting II were: a) the teacher greeted and asked how the students were, followed by calling the names of the students one by one; (b) the teacher related what was learned by students and the lessons to be taught as an effort to refresh students' memories on last meeting; (c) students discussed with the expert groups to put the story together so that it could be understood; (d) the teacher encouraged students to be brave to tell stories in front of the teacher and their friends individually; (e) the teacher asked the students to do a written test in the form of an objective about fairy tales to find out their understanding; ( $f$ ) the teacher gave prizes to students who excelled in storytelling activities; and ( $g$ ) the teacher gave feedback to students.

c. Observation

The position of the researcher was in the back seat to observe directly the storytelling learning. This attitude shown by the researchers intended not to interfere with the course of the lesson. Learning was going well. Students were more enthusiastic and happy to participate in learning to tell fairy tales. The meeting was opened by saying greetings and checking attendance to determine the readiness of students in participating in the learning to be carried out, because Bahasa Indonesia lessons began right after the break was over. Furthermore, students were expected to be able to pay attention to the speaking material delivered by the teacher.

The material taught at this first meeting was still the same, namely the ability to perform storytelling fairy tales using the cooperative method jigsaw techniques. Furthermore, the teacher explained the stages that must be carried out by students, there was division of groups based on the level of students' abilities. Next, the teacher encouraged students to join the expert group to discuss parts of the story. Then after the students exchanged ideas with the expert group, the students went to their original group to inform the results of the discussion in the expert group. The teacher asked students to tell stories in front of the teacher and their friends. This was done after students had discussions with the expert groups. After each group came forward to tell stories in front of the teacher, then the teacher evaluated the storytelling activity, then continued with closing the lesson.

In he next learning activity, the teacher held a discussion about storytelling that had been previously carried out by the students. Then the students were asked to appear individually to tell the contents of the fairy tale they had learned yesterday. To measure understanding of the content of fairy tales, the teacher gave tests to students. The teacher also gave prizes to students who excelled. Furthermore, the remaining time was used by the teacher to conduct reflection in the form of feedback from the teaching and learning process that had been carried out so far. The next activity was the teacher ending the storytelling lesson that day. The researcher would like to thank the teachers, students, and school principals who had been willing to help researchers in carrying out the research. With the help of various parties, the research could 
run smoothly.

Based on the observations of teaching and learning of storytelling, it was known that: (a) students who were enthusiastic in participating in storytelling lessons are $84 \%$, while $16 \%$ while others were less enthusiastic; (b) students who could tell storytelling were $80 \%$, while $20 \%$ of them still seemed confused about telling stories in front of the class. The conclusion was that the enthusiasm of students in the teaching and learning process of storytelling in cycle III was 70\%; (c) meanwhile, the performance results stated: 20 students were telling stories with moderate pronunciation and 2I students were telling stories using great pronunciation; (d) then II students used grammar correctly, 30 students moderately used correct grammar; (e) 3 students were being very fluent in storytelling; 33 students told stories fluently, while 5 students told stories with moderate fluency, and (f) students' understanding of fairy tales was assessed as follows: 36 students could tell stories well and 5 students did not really understand stories. Based on the performance, $87 \%$ of students could complete storytelling better by getting a score of 6.5 .

d. Reflection

Weaknesses in cycle I and cycle II were able to be well resolved in cycle III. The teacher was successful to build the confidence and spirit of students who were initially not confident in telling stories in front of the teacher and their friends who were now optimistic and had self-confidence. Students were more focused on paying attention to the ongoing learning. Some of the students were already willing to express their opinion, the enthusiasm of the students at this stage had increased. When they were given a task to do, they also did it seriously, so that storytelling learning could be said to be successful. The measures of success at this stage had been achieved although it was undeniable that there were still some shortcomings. In addition, students' achievement had improved. Students were optimistic to tell stories in front of the teacher and their friends without any fear so that they were able to convey the contents of the fairy tale in a coherent manner. Based on the learning outcomes in cycle III, speaking skills using the cooperative method jigsaw technique could be said improving. With the increase in achievement shown by students in learning, the action was considered sufficient.

Penelitian ini dilaksanakan dalam tiga siklus. The stages of each cycle included: (I) planning; (2) action; (3) observation; and (4) reflection. The description of the activities from cycles I, II, and III were: First, the researchers carried out observations at SD Negeri 3 Kedungbanteng Banyumas. From observations, information was obtained that the results of the storytelling skills of the third grade students of SD Negeri 3 Kedungbanteng Banyumas were low. Furthermore, together with the teacher, the researchers discussed the appropriate learning method to improve the learning of speaking skills that had been done previously. Researchers and teachers agreed to use the cooperative method jigsaw technique to improve the teaching and learning processes. The cooperative method jigsaw technique was easy to apply in teaching and learning activities. This method was also able to increase student cooperation, train the students to have a sense of responsibility. Then, to carry out the activities in the first cycle, the researchers and the teacher prepared lesson plans. Speaking skills were material that was taught in cycles I, II, and III. In the first cycle, the students were invited to tell the contents of the fairy tale that was shared.

In the first cycle, the students were taught to understand the content of the fairy tale according to the agreement, they were then divided into five groups. Each student was given the task of understanding the content of the fairy tale in the group division which they would then convey at the next group meeting. With the story that had been agreed upon, it was hoped that students would be able to speak fluently because they had read it and at least had memorized it. There were weaknesses found in learning fairy tales storytelling in cycle I. The students were confused and did not understand the method used. In addition, there were students who were not enthusiastic regarding learning activities; it seemed that students were still busy with their own self and joking with their friends and so paid less attention. Reflecting on the weaknesses during the learning activities in cycle I, the researchers and the collaborator discussed and agreed to solve problems and attempted to redesign the lesson plans for cycle II.

Based on the new lesson plans, students were given the freedom to choose groups and were divided into five groups. Besides that, stories had been shared beforehand so that students could learn them at home first. This was done so that the teaching learning processes could be more effective because they felt comfortable with the group they chose themselves; and that the stories had been studied beforehand at home. After that, each group gathered and discussed to combine the stories that had been obtained previously. After they had discussed and understood it, then each group appeared telling stories in front of the teacher and students while the other groups listened to them. At the second cycle meeting, some progress was seen because the students were not afraid anymore to tell stories in front of the teacher and their peers even though there were incomplete groups in telling a story because one of the groups did not pay attention to the discussion.

In the second cycle, there had been an improvement in the learning of storytelling skills which had been 
taught. Students were brave to tell stories in front of their classmates; the story was coherent and clear so that the contents of the story could be understood. However, there were still weaknesses in cycle II, which was that some students still did not pay attention to working together in discussions so that when they came to the front of the class they still looked confused and did not master the material. Seeing the problems that still arose in cycle II, the researchers and the collaborator agreed to find solutions and make lesson plans of the cycle III.

Groups were still formed in the third cycle of the storytelling learning. The groups formed were based on the assessment of cycles I and II. This was done so that students could work together optimally and their abilities could be used optimally. With the application of the methods that had been used in cycles I and II, the students felt used to it. Besides the stories given had been shared beforehand so that they could study it first. Students understood their respective roles when brainstorming with the group. In cycle III there had been a lot of improvement both in students and the teacher. For students, it could be seen through the enthusiasm of students shown when attending lessons, many groups were willing to perform storytelling in front of the teacher and their friends without having to be forced. Not only that, there were those who were willing to come to the front of the class individually. In telling the content of fairy tales, students were fluent and the content told could be understood by their friends. The teacher had done a good job in teaching and learning fairy tales stirytelling in cycle III. Teachers also felt accustomed to using methods in teaching and learning processes, especially in teaching speaking skills. The improvement could be seen from the results of storytelling learning using the cooperative method jigsaw technique at SD Negeri 3 Kedungbanteng Banyumas.

\section{Conclusion}

Based on the activities that have been carried out, the success of learning storytelling using the cooperative method jigsaw technique could be seen from the following measures: (I) the quality of the speaking learning process improved. This can be seen in: (a) students were enthusiastic in learning fairy tales. The evidence was students paid close attention to the teacher when delivering storytelling fairy tale material; and when their friends told stories, other students listened to it. Not only that, students also listened to the teacher's explanation seriously, (b) students were brave to appear speaking in front of the teacher and their peers. It was proven by a voluntary attitude to come to the front of the class without being forced by the teacher and had shown self-confidence. (2) The quality of speaking learning outcomes increased. This could be seen in: (a) the students' storytelling abilities had increased. The evidence was from the scores obtained by the students from cycle to cycle, which was improving. Students were able to tell stories well. In speaking, students were able to speak fluently, clearly and coherently. The words could be understood well and the other students could listen to it well.

\section{Acknowledgement}

The authors would like to thank the Institute for Research Instituted and Community Services (LPPM) Universitas Jenderal Sudirman for funding and supporting this research. Furthermore, we also thank the Bahastra editorial team who had assisted in the publication of this scientific article.

\section{REFERENCES}

Azmi, S. R. M. (2019). Peningkatan Keterampilan Berbicara Menggunakan Metode Bercerita Siswa Kelas V Sekolah Dasar. Journal of Science and Social Research, 2( I), 7-I I.

Beta, P. (2019). Peningkatan Keterampilan Berbicara melalui Metode Bermain Peran. Cokroaminoto Journal of Primary Education, 2(2). https://doi.org/https://doi.org/I0.30605/cjpe.222019.I I8

Febiyanti, D., Wibawa, I. M. C., \& Arini, N. W. (2020). Model Pembelajaran Kooperatif Tipe Jigsaw Berbantuan Mind Mapping Berpengaruh terhadap Keterampilan Berbicara. Mimbar Ilmu, 25(2), I2I. https://doi.org/I0.23887/mi.v25i2.26620

Mabruri, Z. K., \& Aristya, F. (2017). Peningkatan Keterampilan Berbicara Pembelajaran Bahasa Indonesia Kelas Iv Melalui Penerapan Strategi Role Playing Sd N Ploso I Pacitan. NATURALISTIC: Jurnal Kajian Penelitian Pendidikan Dan Pembelajaran, I(2), I I2-I I7. https://doi.org/I0.35568/naturalistic.vIi2.I0

Muna, E. N. dkk. (2019). Upaya Peningkatan Keterampilan Berbicara Menggunakan Media Gambar Siswa Kelas IV SD. Jurnal Pendidikan, 4(I I), I557_-I56I. Retrieved from http://journal.um.ac.id/index.php/jptpp/article/view/I3045/5950

Musaba, Z. (2012). Terampil Berbicara teori dan pedoman penerapannya (2nd ed.). Yogyakarta: CV. ASWAJA PRESSINDO. Retrieved from www.aswajapressindo.co.id

Nupus, M. H., \& Parmiti, D. P. (2017). Peningkatan Keterampilan Berbicara Melalui Penerapan Metode Show 
and Tell Siswa Sd Negeri 3 Banjar Jawa. Jurnal Ilmiah Sekolah Dasar, I(4), 296.

https://doi.org/I0.23887/jisd.vIi4.I2289

Permana, E. P. (2015). Pengembangan Media Pembejaran Boneka Kaus Kaki Untuk Meningkatkan

Keterampilan Berbicara Siswa Kelas Ii Sekolah Dasar. Profesi Pendidikan Dasar, 2(2), I33-I40. https://doi.org/I0.239I7/ppd.v2i2.I648

Pujingsih, R. R. S. H. (202I). Meningkatkan Motivasi dan Hasil Belajar Matematika dengan Metode Kooperatif Tipe Jigsaw di SMA Negeri I Gerung. Paedagogy, 8(I), 50-56. https://doi.org/https://doi.org/I0.33394/jp.v8iI.3196

Rosita, F. Y. (20I5). Pengembangan Multimedia Interaktif Untuk Pembelajaran Berbicara Bagi Siswa Kelas IV Sekolah Dasar. JINoP (Jurnal Inovasi Pembelajaran), I(I), 25.

https://doi.org/I0.222I9/jinop.vIiI.2445

Simanjuntak, E. dkk. (2017). PENINGKATAN PROFESIONALISME GURU SEKOLAH MENENGAH PERTAMA NEGERI (SMPN) DENGAN MELAKUKAN PELATIHAN PENELITIAN

TINDAKAN KELAS. Jurnal Pengabdian Kepada Masyarakat, 23(3), 383-386. Retrieved from https://jurnal.unimed.ac.id/20I2/index.php/jpkm/article/view/7474/6346

Sukma, H. H. dkk. (2020). Pengembangan Modul Bahasa Indonesia dengan Pendekatan Local Wisdom pada Materi Menulis Karangan Narasi untuk Siswa SD. Kiprah, 8(2), I43-I50. https://doi.org/I0.3I629/kiprah.v8i2.I99I

Ummah, N. A. dkk. (2020). Pembelajaran Keterampilan Berbicara di Kelas IV Sekolah Dasar. Jurnal Wanastra, I2(2), I20-I2I. Retrieved from https://ejournal.bsi.ac.id/ejurnal/index.php/wanastra/article/view/8346/4269

Yuliani, W. (2019). Pengaruh Metode Kooperatif Learning Tipe Jigsaw Terhadap Kemandirian Belajar Peserta Ddidik Kelas VI SDN Tunas Bakti Subang Tahun Pelajaran 2018 / 2019. Journal of Chemical Information and Modeling, 53(9), I689-I699. https://doi.org/I0.22460/q.vIiIpI-I0.497

Zahara, S. F. (2020). PENINGKATAN KETERAMPILAN BERBICARA MELALUI STRATEGI MODELLING THE WAY SISWA KELAS X SMK SWASTA JAMBI MEDAN. BAHASTRA, 4(2), 94-99. Retrieved from https://jurnal.uisu.ac.id/index.php/Bahastra/article/view/3153/2096 